PERM JOURNAL OF PETROLEUM AND MINING ENGINEERING ВЕСТНИК ПНИПУ. ГЕОЛОГИЯ. НЕФТЕТАЗОВОЕ И ГОРНОЕ ДЕЛО ISSN 2224-9923 Volume/ Tom 19 №2 2019

http://vestnik.pstu.ru/geo/

UDC 622.276+622.807.2:622.273

Review / Обзор

(C) PNRPU / ПНИПУ, 2019

\title{
METHODS OF DUST SUPPRESSION AT OPEN-PITS COAL MINES OF EXTREME NORTH
}

\author{
Nikita A. Sharov, Ruslan R. Dudayev, Denis I. Krishchuk, Maria Yu. Liskova
}

Perm National Research Polytechnic University (29, Komsomolskiy ave., Perm, 614990, Russian Federation)

\section{МЕТОДЫ ПЫЛЕПОДАВЛЕНИЯ НА УГОЛЬНЫХ РАЗРЕЗАХ КРАЙНЕГО СЕВЕРА}

\section{Н.А. Шаров, Р.Р. Дудаев, Д.И. Крищук, М.Ю. Лискова}

Пермский национальный исследовательский политехнический университет (614990, Россия, г. Пермь, Комсомольский проспект, 29) Received / Получена: 12.11.2018. Accepted / Принята: 01.06.2019. Published / Опубликована: 28.06.2019

Keywords:

open-pit coal mines, dust, dust sources, dust suppression methods, opencast mining, coal, air dustiness, dust control, dust load, negative temperature, mineral resources, mining, strip-mine, fuel, Extreme North.
Ключевые слова: угольные разрезы, пыль, источники пылеобразования, методы пылеподавления, открытые горные работы, уголь, запыленность воздуха, борьба с пылью, пылевая нагрузка, отрицательные температуры, полезное ископаемое, добыча, карьер, топливо, Крайний Север.
At present, the Russian coal industry is demonstrating an increase in coal production against the background of increased mineral exports. Coal mining in the Russian Federation is carried out by opencast and underground mining methods; currently 59 underground mines and 108 open-pit coal mines are operating.

High concentration and intensification of all technological processes related to mining and processing of minig raw materials is the specifics of the present-day stage of mining development at coal strip mines. This all is accompanied by complication of the process of ventilation of mined-out space of the strip mine, deterioration of working conditions with dust and gas factors, and negative effect on the human health and environment.

At dust release exceeding $58 \mathrm{~kg} /$ ha per month, the effect of vital activity suppression of the majority of flora and fauna in the given area is observed. The inhaled dust causes acute upper respiratory tract illnesses. The accumulation of dust from explosive and combustible materials in the air poses a risk of explosion or fire. Increased dust levels produce a negative impact on machinery. In addition to purely mechanical wear caused by abrasive particles entering the moving parts, machine control systems can also malfunction, as more dust enters the electronic control units.

The lifespan of an engine functioning in the dusty conditions is reduced by 2-3 times. Exposure to dust increases the intensity of the corrosion process, while machinery maintenance and repair becomes more complicated and time-consuming.

Therefore, dust suppression is an extremely important measure to be applied in many industries. Dust suppression is a very broad concept. This Article studies only one aspect of the issue: a complex of methods and means. Various methods and equipment are used to combat dust: from complex stationary exhaust ventilation systems, cyclone separators and electrostatic dust collectors to sprinkler installations, hydraulic mining giants and fog cannons spraying water, chemicals and foam.

sprinkler installations, hydraulic mining giants and fog cannons spraying water, chemicals and foam.
This Article analyses the specifics of mining in subzero conditions, dust sources, dust effect on human health and dust suppression methods used at open pits in general, and also examines the problem of dust suppression at open pits in the Extreme North. This is a pressing issue, as of today, as many coal-mining enterprises in Russia operate in low temperature conditions.

В настоящее время угольная промышленность России демонстрирует наращивание добычи угля на фоне увеличения экспорта полезного ископаемого. Добыча угля на территории Российской Федерации производится открытым и подземным способами, на данный момент действует 59 шахт по добыче подземным способом и 108 угольных разрезов. Особенностью современного этапа развития горных работ на карьере является высокая концентрация и интенсификация всех технологических процессов, связанных с добычей и переработкой горнорудного сырья. Отмеченное сопровождается усложнением процесса проветривания выработанного пространства карьера, ухудшением условий труда по пылевому и газовому факторам, негативным воздействием на организм человека и на окружающую среду.

При поступлении пыли более 58 кг/га в месяц наблюдается эффект угнетения жизнедеятельности большинства растений и животных в данном районе. Вдыхаемая пыль вызывает острые заболевания верхних дыхательных путей. Накопление в воздухе пыли взрывоопасных и горючих материалов грозит опасностью взрыва или возгорания. Повышенное количество пыли отрицательно сказывается на состоянии техники. Помимо чисто механического износа из-за попадания абразивных частиц в трущиеся детали возможны сбои систем управления машиной, так как повышенное количество пыли попадает в электронные блоки управления.

Ресурс двигателей, работающих в условиях запыления, сокращается в 2-3 раза. Воздействие пыли увеличивает интенсивность процесса коррозии, обслуживание и ремонт техники становятся сложнее и продолжительнее по времени. Поэтому подавление пыли - чрезвычайно важное мероприятие, которое применяется во многих отраслях. Пылеподавление - очень широкое понятие. В данной статье рассмотрена только часть этого вопроса - комплекс способов и средств. Для борьбы с пылью используются разнообразные способы и оборудование - от сложных стационарных вытяжных вентиляционных систем, сепараторов-циклонов и электростатических пылеуловителей до дождевальных установок, гидромониторов и туманообразующих пушек, распыляющих воду, химические вещества и пену.

В данной статье проанализированы специфика отработки полезных ископаемых в условиях отрицательных температур, источники пылеобразования, влияние пыли на организм человека и методы пылеподавления, которые используют на угольных разрезах в целом, а также рассматривается проблема пылеподавления на угольных разрезах Крайнего Севера. Данная проблема является актуальной на сегодняшний день, так как многие угледобывающие предприятия России действуют в условиях низкого температурного режима.

Nikita A. Sharov (tel.: +007951922 54 75, e-mail: sharov.nickita@yandex.ru).

Ruslan R. Dudayev (tel.: +007 98249166 96, e-mail: dudaevruslan69@gmail.com)

Denis I. Krishchuk (tel.: +7 950 4657995, e-mail: ms.den.best@mail.ru)

Maria Yu. Liskova (Author ID in Scopus: 55749420800) - PhD in Engineering, Associate Professor of the Department of Life Safety (tel.: +0079223116764 e-mail: liskova.rpb@gmail.com). The contact person for correspondence.

Шаров Никита Андреевич (тел.: +007 95192254 75, e-mail: sharov.nickita@yandex.ru).

Дудаев Руслан Робертович (тел.: +007 98249166 96, e-mail: dudaevruslan69@gmail.com).

Крищук Денис Игоревич (тел.: +7 950 4657995, e-mail: ms.den.best@mail.ru).

Лискова Мария Юрьевна - кандидат технических наук, доцент, доцент кафедры безопасности жизнедеятельности (тел.: +007922 3116764 , e-mail: liskova.rpb@gmail.com). Контактное лицо для переписки. 


\section{Introduction}

Coal is a mineral resource, a type of fuel, which is a source of $40 \%$ of the world's electric power. This is a mineral, without which it is impossible to smelt cast iron and ferroalloys. This mineral comes in three forms: stone coal, brown coal and anthracite [1].

The Russian coal industry demonstrates a rise in coal production against the background of increased mineral exports. However, since coal is considered to be the most 'dirty' type of fuel, it is falling under the new continually toughening environmental requirements [2]. In this respect, all coal-consuming countries are introducing programs for transition to renewable energy sources and programs of general gas infrastructure development.

Despite all this, the amount of consumed coal will not decrease, but it is its world share in electric power production that will decline [3]. To reduce the coal industry risks, Russia should prioritise export to the countries of the East and production of coking and anthracite coal, the demand for which should never drop.

Coal mining in the Russian Federation is carried out by opencast and underground mining methods; currently 59 underground mines and 108 open-pit coal mines are operating. Their total production capacity is 435 million tonnes of coal. The number of employees in the coal-mining industry is 130 thousand people.

The distinctive feature of coal mining, in comparison with other minerals, is increased dustiness in mines and open pits, danger of breakthrough of poisonous and explosive gases and probability of mine ignition that is very hard to extinguish [4].

The country's main coal deposits are located in the southeast; there are also large reserves of quality coal in the north-east of the country. The key coal mining enterprises include:

1. SUEK, operating 15 mines and 12 open-pit coal mines in Siberia and the Russian Far East, accounting for approx. $27 \%$ of the coal produced in Russia. In 2017, the company produced 107.8 million tons of coal [5].

2. Kuzbassrazrezugol, operating in the Kemerovo region, owns 6 open pits and 1 coal mine, annually producing 46 million tons of coal [5].
3. SDS-Coal, producing 30 million tons of coal per year at its 4 open pits cand 2 coal mines [5].

Currently, there is interest in coal production in the Extreme North of Russia. This interest has emerged due to the availability of a sufficient number of heavy-duty icebreakers in the Russian fleet. At present, Russia has 41 icebreaker, 8 of them are nuclear-powered [6]. For comparison, in the whole world there are only 80 icebreakers. Global warming is another reason, as it has increased the average air temperature by $0.74{ }^{\circ} \mathrm{C}$ and reduced the ice surface area by $25 \%$ [7] over the last 100 years. All this provides prospects to develop new fields in the Arctic region of Russia and for the Northern Sea Route to compete with Suez Canal.

In order to study dust suppression at the northern coal enterprises, we have examined the Yunyaginsky open-pit coal mine (Komi Republic) and two mines, Severnaya and Zapolyarnaya, located in Vorkuta (Komi Republic). Critical problems with dust suppression in the Extreme North conditions were identified, arising due to low humidity and the impossibility or high cost of applying traditional dust control methods. However, we can only rely on the practice of the Yunyaginsky open pit when studying dust suppression.

Before proceeding to the studies of dust suppression methods at coal strip mines in the Extreme North, it is necessary to determine the specifics of mining in these climatic conditions, dust sources, dust effect on human health and dust suppression methods used at open pits, in general.

\section{Specific features of coal strip mining at subzero temperatures}

The Arctic regions of Russia are characterrized by the impact of extreme physical and climatic conditions, the focal nature of population settlement and development and the lack of regular transport infrastructure. For example, for several hard-to-reach regions of Yakutia, the cost of delivery exceeds the cost of production so much that the local coal deposits are only developed in immediate vicinity to the main consumption spots (8).

Thus, along with extreme physical and climatic conditions, the Arctic regions of the Russian 
Federation are characterized by high energy intensity and low efficiency of natural resources extraction (9).

The problem of northern supply haul (provision of necessary supplies to the population residing on this territory) should be noted separately. At present, it is proposed to address this issue by using renewable and alternative energy sources, including local ones.

Electric power supply to the Arctic zone in the north-east of Russia is provided from decentralized diesel power plants and separate isolated power units (10). Mining companies are industrial consumers of thermal energy and electric power. No significant growth in energy consumption is anticipated in the near and middle-term future.

At present, the existing coal-mining enterprises participating in coal deliveries to the region or supplying it to the adjacent areas use traditional opencast or underground geotechnologies. In doing so, they encounter the following production complications: inadequate equipment, high depreciation of fixed assets and shortage of qualified personnel. Depreciation charges and profit received do not cover performance of appropriate renovation activities [11].

Construction of industrial and household facilities on the ice shell of permafrost, which is constantly changing its structure, is highly challenging. The loose soils - sandstones, pebbles and clays - behave in the most unpredictable way in permafrost conditions. As the structures erected on them warm up the soil, it loses its solidity and starts melting and shifting. Building the structures' foundations in permafrost is only possible by taking special measures to maintain a constant ground temperature [12].

Strong winds and frequent blizzards consitute another northern climate pattern confronted by the enterprises. For example, northern Yakutia features extremely severe weather conditions, where the windspeed of $1 \mathrm{~m} / \mathrm{s}$ lowers the felt air temperature by two degrees. As an illustration, when the temperature is $-40{ }^{\circ} \mathrm{C}$ and the windspeed is $18 \mathrm{~m} / \mathrm{s}$, the apparent tempreature is as low as $-80{ }^{\circ} \mathrm{C}$ ! The local climate is only exceeded by the Antarctic climate in harshness [13].

In addition, mining operations are usually accompanied by intense dusting and dust emissions into the environment. The area covered by dust emissions is usually 10 times larger than the size of industrial sites [14].

The importance of this environmental factor in the development of deposits in the cryolithic zone increases manyfold due to powerful transboundary flows of passive pollution [15].

Sun cycle is another distinguishing feature in the conditions of the Extreme North and the Arctic, in particular. Here, the whole year is divided into polar day and polar night, each half a year long.

All the above features make mining in the Extreme North higly challenging.

\section{Dust sources at coal strip mines}

The dust environment in open pit in general and its separate sites is largely dependent on the presence, composition and nature of moving air flows that mainly determine the amount of hazardous substances brought to, generated in and removed from the open pit, and sometimes can cause intensive dust formation [16-18]. Also, air dustiness in the open pit is determined by the distance from the dusting source and climatic conditions. The dusting sources at coal strip mines during mining and processing of minerals are listed in Tab. $1[19,20]$.

The analysis of literature sources shows that despite the application of different dust suppression methods, dust concentration at all stages of coal mining at the open pits exceeds the norms of maximum allowable concentrations (MAC) [13], established for the working zone air environment.

For example, at the enterprises conducting active coal mining at the deposits of Kuznetsk and Irkutsk coal basins, the most adverse working conditions were revealed on the workplaces of drivers and operators of heavy machinery, with high degree of dustiness, considerably exceeding the norm (Table 2).

\section{Effects of dust on human health}

Exposure to occupational hazards, typical of all labor processes of coal mining, results in the development of occupational diseases of the industry personnel, which leads to major damage to enterprises and the state, in general, causes irreparable health damage to the coal industry personnel and reduces life expectancy $[21,22]$. 
Main Sources of Air Dust Pollution at Mining Enterprises [20]

\begin{tabular}{|c|c|}
\hline $\begin{array}{l}\text { Main Industrial Processes } \\
\text { and Facilities }\end{array}$ & Pollution Sources \\
\hline Preparation of rocks for extraction & $\begin{array}{l}\text { 1. Dust from well drilling. } \\
\text { 2. Dust from blasting. }\end{array}$ \\
\hline Extraction and loading & $\begin{array}{l}\text { 1. Dust from rock mass extraction and loading to transportation vehicles and cutting for disposal } \\
\text { by various extracting machinery. } \\
\text { 2. Dust from rock mass extraction by excavating and excavating-transporting machines with } \\
\text { combustion engine (diesel-driven excavators, loaders, scrapers, bulldozers). }\end{array}$ \\
\hline Transportation of strip mine loads & $\begin{array}{l}\text { 1. Dust from strip mine roads. } \\
\text { 2. Blowing of dust from transportation vehicles at transportion of minerals, waste rock and rock } \\
\text { refuse. } \\
\text { 3. Dust at transfer points. }\end{array}$ \\
\hline $\begin{array}{l}\text { Dumping and storage of waste rock, } \\
\text { rock refuse and minerals }\end{array}$ & $\begin{array}{l}\text { 1. Dust from rock piling to dumps and storage. } \\
\text { 2. Dusting of exposed surfaces of waste rocks dumps, minerals storage and sludge collectors. }\end{array}$ \\
\hline Borrow cuts & 1. Blowing of dust from dump and site surfaces. \\
\hline $\begin{array}{l}\text { Site facilities: } \\
\text { - crushing, screening, agglomerating } \\
\text { and dressing plants; } \\
\text { - boiler units; } \\
\text { - production machinery and vehicles } \\
\text { depots }\end{array}$ & $\begin{array}{l}\text { 1. Dust from unloading, crushing and grading of minerals. } \\
\text { 2. Dust from roasting at mineral processing. } \\
\text { 3. Dust from boiler unit operation. } \\
\text { 4. Dust from operation without production machinery. }\end{array}$ \\
\hline
\end{tabular}

Table 2 According to the International Labour

Dust Level at Workplaces

in Kuznetzk and Irkutsk Basins [23-25]

\begin{tabular}{|l|c|c|}
\hline \multicolumn{1}{|c|}{ Workplace } & $\begin{array}{c}\text { Average level } \\
\text { of dust } \\
\text { concentration, } \\
\mathrm{mg} / \mathrm{m}^{3}\end{array}$ & $\begin{array}{c}\text { Value } \\
\text { exceeding } \\
\text { MAC, } \mathrm{mg} / \mathrm{m}^{3}\end{array}$ \\
\hline Driver of BelAZ truck, 30 t capacity & $7.4 \pm 1.2$ & $5.4 \pm 1.2$ \\
\hline Driver of BelAZ truck, 42 t capacity & $7.0 \pm 1.1$ & $5.0 \pm 1.1$ \\
\hline Driver of BelAZ truck, 170 t capacity & $6.1 \pm 1.0$ & $4.1 \pm 1.0$ \\
\hline Driver of BelAZ truck, 200 t capacity & $6.2 \pm 1.6$ & $4.2 \pm 1.6$ \\
\hline Operator of T-500-P-1 bulldozer & $5.8 \pm 2.9$ & $3.8 \pm 2.9$ \\
\hline \multicolumn{2}{|c|}{ Irkutsk basin } & $16.5 \pm 3.0$ \\
\hline Bulldozer operator & $16.0 \pm 0.2$ & $14.0 \pm 0.2$ \\
\hline Wheeled vehicle operator & $18.1 \pm 0.4$ & $16.1 \pm 0.4$ \\
\hline Dump truck driver & $14.9 \pm 0.2$ & $12.9 \pm 0.2$ \\
\hline Excavator operator & $15.4 \pm 0.1$ & $13.4 \pm 0.1$ \\
\hline Drill rig operator & \begin{tabular}{c}
$\mid c .2$ \\
\hline Blaster
\end{tabular} & $8.1 \pm 0.2$ \\
\hline
\end{tabular}
Organization, the fatality rate from occupational accidents and diseases is 2.34 million people, annually. The overwhelming majority of these fatalities, approx. 2.02 million, is related to a range of occupational diseases (26).

In Russia, the highest level of occupational diseases is among personnel of mineral production enterprises [27]. Thus, in 2015, the proportion of mining industry personnel engaged in operations in harmful and hazardous working environments constitued $56.5 \%$. At the same time, in spite of technical re-equipment, the first in the list is the coal mining industry, where the proportion of the considered category of personnel makes up $79.7 \%$ from the total number of those occupied in this industry [28-30].

Production environment at coal open pits is characterized by a combination of harmful factors of working process affecting human health [31, 32]. The harmful occupational factors may include, among others, coal and rock dust aerosols, noise, vibration, temperature conditions, air humidity, harmful gases, etc [33, 34].

The risk of occupational diseases of dust etiology depends on the following factors [16]: 
1) dust concentration, duration and intensity of exposure;

2) individual susceptibility to dust and presence of factors predisposing to the development of fibrosis;

3) physical and chemical properties of dust, geometric parameters of particles and their aerodynamic properties.

It has been established $[35,36]$ that the effect of dust on the body when inhaling dusty air has an accumulative character. Important is the way of inhaling: through nose or through mouth. The considerable part of dust (up to $90 \%$ ) is trapped by mucous membrane of nose, nasopharynx, trachea and bronchi, as it passes through respiratory tract, the other part penetrates into lower respiratory airway where it stays. At long-term exposure to dust the protective action of mucous membrane decreases, inducing changes in upper airway that cause dust bronchitis disease [37]. Prolonged contact with fine dust fractions (up to $5 \mu \mathrm{m}$ ) may provoke pneumoconiosis [38].

Thus, in China pneumoconiosis is the most widespread work-related disease, accounting for more than $80 \%$ of all registered cases of occupational diseases. According to the latest data, from 10 to 23 thousand cases of diseases are registered there annually. In India, 10 million workers employed in mining, construction and other industries are affected by silicon dust [39, 40].

In Vietnam, pneumoconiosis accounts for $75.7 \%$ of occupational morbidity cases, with sickness benefits to the personnel. In Brazil, 6.6 million workers are affected by silicon dust. The research in Latin America showed that $37 \%$ of underground labourers are diagnosed with silicosis, $50 \%$ of miners are over 50 years of age. The epidemiological studies in developing countries confirm that between $30 \%$ and $50 \%$ of mining workers may suffer from silicosis and other pneumoconiosis deceases (39).

According to official data, 1 million people in the USA have pneumoconiosis. More than $50 \%$ of underground mining workers in Japan suffer from pneumoconiosis; in Austria, from $2 \%$ to $20 \%$ of miners have this disease. In England, more than 5 thousand cases of pneumoconiosis are registered annually. Often, pneumoconiosis is fatal. Among the diseased in the USA, about 2 thousand people die annually, and 1,300 people in England [41].
As can be seen from the above, the level of occupational morbidity in the coal industry is very high both in Russia and globally.

As the analysis shows, coal mining generates a considerable amount of dust that, in its turn, affects human health and is highly hazardous [42]. It is therefore necessary to apply various methods of dust suppression, which will be considered below.

\section{Methods of dust suppression at strip mines}

The production process of opencast coal mining is associated with a high level of occupational risk, resulting chiefly from the intensive inhalation exposure to coal dust in the setting of an adverse microclimate [43].

Dust control at mining enterprises includes dusting formation prevention, dust suppression and dust collection. Where it is impossible to completely exclude dusting along with dust collection at mining enterprises at various technological processes, the dust suppression in the atmosphere (coagulation) and its deposition immediately in dusting areas, as well as dedusting (artificial) ventilation through dilution and removal of dust cloud, are widely used [44].

In opencast mining, all dusting sources can be divided into local (point) and area sources, as shown in Fig. 1.

Compared to local sources, the area sources have significant dusting surfaces and, as a result, larger volumes of polluted air. Therefore, the dust control methods should be more extensive [19].

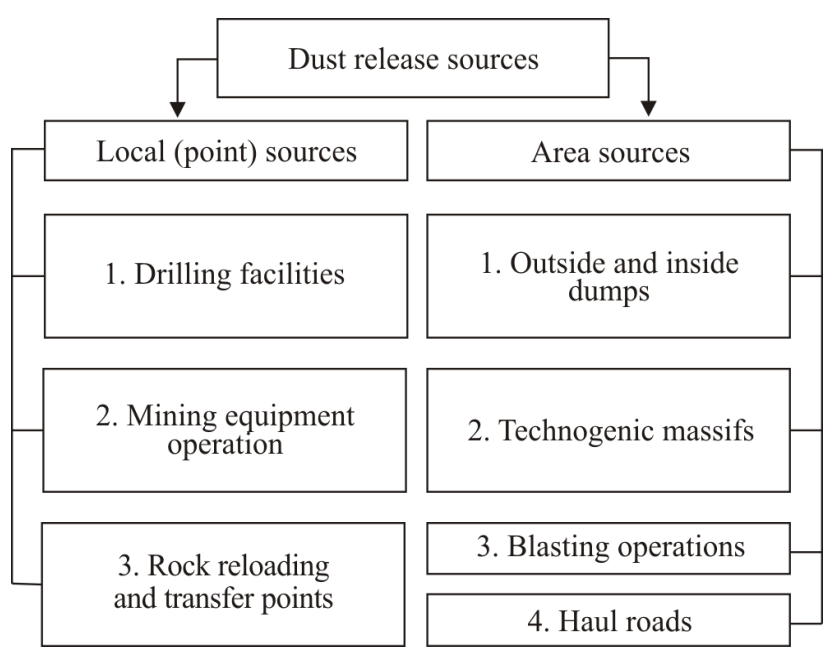

Fig. 1. Dust Release Sources at Open Pits 
Dust control at the enterprises of a mineral resources sector can be performed at different stages of its generation, as following: at formation of dust fraction solid particles as a result of production process, at blowing (whirling-up) of dust particles, and directly in dusty air $[45,46]$.

There are different ways to reduce airborne dust concentration: by preventing dust generation, by dust deposition through coagulation processes, by filtering of dusty air, by ventilation through dilution and removal of dust cloud from the atmosphere [46].

There are four directions of dust control at mining enterprises: organizational, technological, technical and biological. Each of them can be implemented in combination with the others, while the comprehensive approach to addresing specific problems is supported by economic, energy, health or environmental criteria [47, 48].

Organizational methods are aimed at optimisation of production processes related to the mode of mining operations and include technological and natural constituents [46].

Technological methods of dust suppression comprise measures for technology and processes optimisation, working equipment upgrade and new equipment application [46].

Technical methods of dust suppression, are primarily related to application of equipment reducing dust formation and dust separation, and suppressing dust release. All of them can be divided into two types: wet and dry [46].

Biological methods of dust suppression include application of materials of organic origin (biogenic methods) as well as use of living nature resourses (biocenotic methods) [46].

Despite the considerable scope of the conducted studies in the field of dust release and dust transfer reduction and the proposed structural solutions, the practical results are rather modest due to the fact that little attention was given to the aspects of enhancing the efficiency and operability of the proposed devices and optimisation of their functioning [46].

In this connection, the search for efficient means and ways to reduce dust and gas emissions into the atmosphere remains a crucianl task. Wet methods are the most promising and sophisticated ones $[49,50,51]$; they are implemented through humidification of dust-forming raw materials and dusty material, irrigation of airborne dust with solutions and its consolidation with liquid (gellike) substances.

Of particular interest are the wet methods of dust emissions control at all stages of the process using the effects of change of 'steam - liquid - ice' phase [46].

The analysis of scientific studies and technical solutions aimed at reduction of dust emission under conditions of opencast mining has shown that the principal method of dust control at point and area sources of dust suppression is wet dedusting (irrigation), i.e. the collection and deposition of solid particles of dust with liquid drops [52-55].

Water dust suppression is one of the most widespread measures to reduce the dust load in the open pits [56]. The efficiency of water dust suppression by sprinklers subject to the wind resistance of the coating reaches $95 \%$. At subzero temperatures, ice is formed at the spraying nozzle tip, which hinders the liquid flow and affects the quality of the resulting aerosol. Since in the process of dust particles coagulation with water in winter the water freezes and can not fully come into contact with the dust, it makes water irrigation ineffective for year-round dust suppression, i.e. the effectiveness drops to approx. $40 \%$. This method fails to comply with the needs of the enterprise for safe uninterrupted system operation, in general [46].

Another main direction of reduction of dust load on working zone of construction materials strip mines resulting from the aerial technogenic impact of outside rock dumps is the reduction of dust emission through application on their surface of a protective biogenic coating consisting of a mixture of vermicompost and sodium carboxymethylcellulose, to their surface. It has been established that application of the biogenic protective layer consisting of a mixture of vermicompost and sodium carboxymethylcellulose reduced dust emission by 10-11 times and increased bioproductivity of the reinforced surface of outside dumps by $90 \%$, subject to the ratio of the mixture components $125: 1$ and the layer thickness of $3 \mathrm{~cm} \mathrm{[57].}$

Dusting on haul roads also plays an important role in the process of dust suppression at open pits. Intensive dusting decreases speed and performance 
of road transport, results in intensive wear and tear of parts and components of vehicles, and poses occupational risks for the pit personnel. Dust content in the air near roads is $0.5-10.3 \mathrm{~kg} / \mathrm{m}^{3}$, intensity of dust emission on roads is $0.014 \mathrm{~kg} / \mathrm{s}$. The dispersability of airborne dust is extremely high: $90-98 \%$ of dust particles are less tha 10 microns in size, which indicates a potential hazard of pneumoconiosis due to the content of free silica in the form of quartz; its amount reaches $40-42 \%$ [58]. The introduction of surfactants in this situation may prove the most efficient yearround dust control.

Currently, there is a wide range of surfactants that form a flexible film on the road surface, which can bind rock and coal dust and significantly reduce dust formation from heavy-duty vehicles for approx. 14 days. For example, RNX-1020 surfactant produced by Rosneftekhim retains its effectiveness in conditions of rainy weather and can be used on open-pit roads at temperatures down to $-50{ }^{\circ} \mathrm{C}[59]$.

In the case of blasting operations, dust suppression shall be performed through extended (before, during, and after blast) treatment of the dust and gas cloud with finely sprayed ionized liquid from irrigation units located in an alternating (by ion-charge) order outside the zone of their possible damage or destruction from the blasting [60].

Fig. 2 shows the effectiveness of dust suppression methods subject to year-round dust suppression.

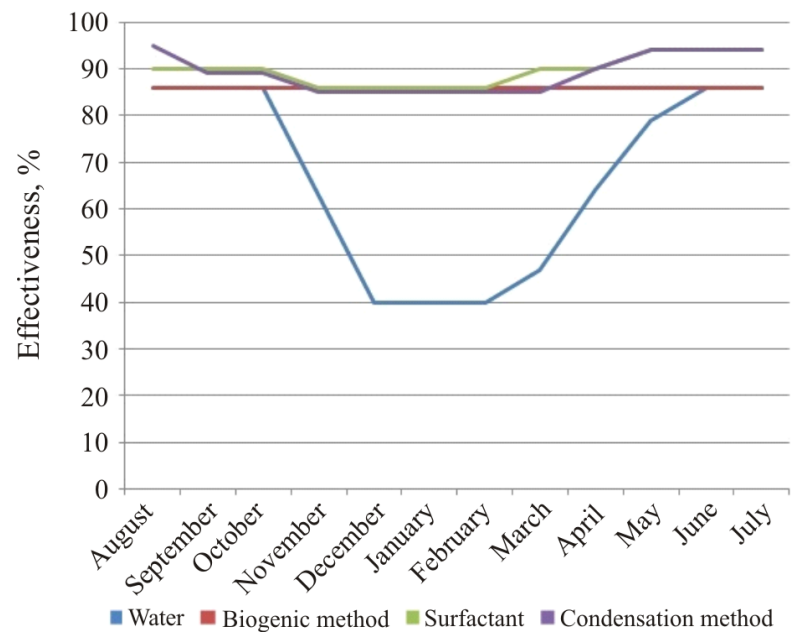

Fig. 2. Dependency of effectiveness of various dust suppression methods on time of year
In addition to these measures, aerosol collection equipment is available to help clean the polluted air and remove particularly fine fractions [61].

Dry, wet and electrostatic purification methods are used to collect aerosols with installations and devices of various designs [62]. The choice of the method and device for aerosol collection is made depending on its particle size distribution (Table 3).

Where technical measures can not reduce air dustiness at workplaces to the maximum allowable concentration, it is mandatory to use personal protective equipment for dust protection [63].

Therefore, the mechanism of dust environment improvement at mining enterprises consists in the dust formation prevention, dust suppression and dust collection. To collect aerosols, dry, wet and electrostatic methods of purification using installations and devices of various design are used. The key methods of dust suppression include wet dedusting, application of surfactants, biogenic and condensation methods.

Technical measures do not always provide a full-featured safe dust environment at the workplace (reducing air dustiness to the maximum allowable concentrations); in such cases, the use of personal respiratory protection equipment is mandatory [64].

Table 3

Selection of equipment depending on dust disperability

\begin{tabular}{|c|c|c|}
\hline $\begin{array}{c}\text { Particle Size, } \\
\mu \mathrm{m}\end{array}$ & $\begin{array}{c}\text { Purification } \\
\text { Methods }\end{array}$ & Equipment \\
\hline $40-1000$ & Dry & Dust presipitation chambers \\
\hline $20-1000$ & Dry & $\begin{array}{c}\text { Centrifugal collectors, } \\
\text { diameter of } 1-2 \mathrm{~m}\end{array}$ \\
\hline $5-1000$ & Dry & $\begin{array}{c}\text { Centrifugal collectors, } \\
\text { diameter of } 1 \mathrm{~m}\end{array}$ \\
\hline $20-100$ & Wet & Scrubbers \\
\hline $0.9-100$ & Dry & Fabric collectors \\
\hline $0.05-100$ & Dry & Fibrous collectors \\
\hline $0.01-100$ & Electrostatic & Electrostatic precipitators \\
\hline
\end{tabular}


We can state that there is a range of dust suppression methods, by having analysed them, yet not all of such methods can be used at subzero temperatures. Therefore, it is necessary to analyse what dust suppression methods are applicable in the Extreme North conditions.

\section{Methods of dust suppression at strip mines in the Extreme North}

The 'Guidelines for Dust Control at Slate Quarries and Dust Explosion Protection at Coal and Slate Quarries" [65] stipulate additional requirements for dust control at negative temperatures at at slate quarries, which include dust control measures at quarry faces and loading and unloading operations.

As early as in 1984, scientists were sttudying a condensation method of dust suppression at reloading of mined rock in the strip mines at negative temperatures. The studies $[66,67]$ demonstrate feasibility of application of the heated sprayed water for condensation dust suppression at reloading of rock mass at open-cast mines at negative temperatures. In this cse, the efficiency of condensation dust suppression depends both on water temperature and consumption, and on temperature and initial dustiness of air.

The study [67] provides the calculation procedure for heated water consumption for condensation dust suppression at reload of mined rock at strip mines at subzero temperatures. The work [67] established that increase in water temperature enhances the dust suppression efficiency by 1.1-4.2 times; if the temperature of supplied water is $95{ }^{\circ} \mathrm{C}$, then $85-86 \%$ of the dust particles of less than $5 \mu \mathrm{m}$ are collected. The influence of air temperature on the efficiency of dust deposition was studied. The experiments were carried out with hot $\left(95{ }^{\circ} \mathrm{C}\right)$ water at the air temperature of $0 ;-100 ;-200{ }^{\circ} \mathrm{C}$. The analysis of the obtained results allowed us to conclude that with the drop of air temperature, the deposition efficiency increases to reach $80-90 \%$ and more at the ratio of hot water and dust of $(0.8-1.3) \cdot 103$ $\mathrm{kg} / \mathrm{kg}$. This can be explained by the process intensification through obtaining higher oversaturation at low negative temperatures. It was established that for the condensation dust suppression in conditions of negative temperatures it is recommended to use water heated to $80-95{ }^{\circ} \mathrm{C}$ at the rate of $300-800 \mathrm{~kg}$ per $1 \mathrm{~kg}$ of released dust.

Many coal-mining enterprises in Russia operate in low-temperature conditions. In this connection, labour activity demands application of special personal protective equipment [68]. In this case, further to the basic function of respiratory protection, the personal protective equipment provides protection against ambient low temperatures. These include a self-contained air-fed respiratory protective device, self-contained breathing respirator, oxygencylinder breathing apparatus, and air-conditioning respirator [69].

Protection against cold by heating the inhaled air by respiratory devices helps to reduce heat loss for warming up the inhaled air. In general, this process helps to maintain normal body thermal status and, consequently, increases the performance level [70].

Designed to increase the temperature of inhaled air at low negative temperatures, these devices yet have common shortcomings in operation or design. In this case, at temperatures below $-30^{\circ} \mathrm{C}$ the material of the body, filter, heat exchanger and the condensate freeze, which increases breathing resistance [71].

Technical measures do not always provide a fullfeatured safe dust environment at the workplace (reducing air dustiness to the maximum allowable concentrations); in such cases, the use of personal respiratory protection is mandatory.

However, many coal mines and open pits operate in regions with low temperature conditions. Therefore, it is necessary to use special personal protective equipment subject to the negative ambient temperature at these enterprises. The essential equiment includes a self-contained air-fed respiratory protective device, oxygen-cylinder breathing apparatus, self-contained breathing respirator, and air-conditioning respirator.

\section{Conclusion}

Summing up what has been said, it was established that adverse labor factors at the mining facilities of the Extreme North include low air and rock temperatures; high humidity; often - high velocity of air flow along main roadways; dust, explosive and exhaust gases; noise, vibration, bleeding of toxic gases; increased risk of injury and 
development of occupational diseases. The crucial adverse occupational factor at the majority of mining facilities in the North is dust, its concentrations depending on the development technology, mineral type, equipment used, production job, and implementation of dust prevention measures. Therefore, dust concentrations at work places vary widely. Due to the complicated application of dust control means, mostly, at mining enterprises of the Extreme North, such concentrations are considerably higher than the levels detected at the facilities located in moderate climate of central Russia. Dust levels at open-pit mineral mining sites in the North are generally lower than at mines, depending on the pit depth, the mining equipment used and the weather conditions.

Most of the experts agree on the absence of a single solution to all the complicated dust control issues and an all-in-one fully safe and productive dedusting method. In each case, these issues are to be addressed individually. The complex of measures on reduction of industrial environment factors affecting the miners should include application of personal protective equipment. At the same time, it should be realised that PPE cannot replace application of fundamental and integrated technical measures for dust control, including dust collection and suppression.

\section{References}

1. World of molecules, available at: https://www.worldofmolecules.com/fuels/coal7b.htm (accessed 25 October 2018).

2. The Guardian, available at: https://www.theguardian.com/commentisfree/2009/feb/15/james-hansenpower-plants-coal (accessed 25 October 2018).

3. Coal's decade of stagnation, available at: https://www.iea.org/coal2017 (accessed 25 October 2018).

4. The prevention and control of fire and explosion in mines, available at: http://www.hse.gov.uk/ mining/feguidance.pdf. (accessed 25 October 2018).

5. Nezavisimoe analiticheskoe agentstvo "Rosinformugol" [Independent analytical agency "Rosinformugol"], available at: https://www.rosugol.ru/index.php. (accessed 25 October 2018).

6. Does the U.S. stand a chance against Russia's icebreakers?, available at: https://www.popularmechanics.com/military/navy-ships/a19673250/futureicebreakers (accessed 25 October 2018).

7. Trubetskoi K.N. Geotekhnologicheskaia paradigma razvitiia kompleksnogo osvoeniia nedr $\mathrm{v}$ Arkticheskoi zone rossii [Geotechnological paradigm of development of integrated mineral resources development in the Arctic zone of Russia]. Moscow, 2015, 12 p.

8. KOLMAR South Yakutia Coal, available at: http://www.kolmar.ru/upload/iblock/b0d/b0dceaf572 9be2ae739e9599a0f06911.pdf (accessed 25 October 2018).

9. Rossiiskaia gazeta RG.RU [Rossiyskaya gazeta RG.RU], available at: http://www.rg.ru/
2009/03/30/ arktika-osnovy-dok.html (accessed 25 October 2018).

10. The development strategy of the Arctic zone of the Russian Federation, available at: http://www.iecca.ru/en/legislation/strategies/item/99the-development-strategy-of-the-arctic-zone-of-therussian-federation (accessed 25 October 2018).

11. Tkach S.M. et al. osvoenie ugolnykh mestorozhdenii $\mathrm{V}$ udalennykh raionakh severovostoka Arktiki - osnova obespecheniia energobezopasnosti naseleniia regiona [The development of coal deposits in remote areas of the north-eastern Arctic - the basis for ensuring the energy security of the population of the region], available at: https://docplayer.ru/32006093-Osvoenie-ugolnyh-mestorozhdeniy-v-udalennyh-raonah-severo-vostoka-arktiki-osnova-obespecheniya-energo bezopasnosti-naseleniya-regiona.html (accessed 25 October 2018).

12. Institut promyshlennogo grazhdanskogo proektirovaniia [Institute of industrial civil engineering], available at: http://2k-project.ru/obinstitute/sobytiya_i_novosti/news/news_2k/ctatya-vzhurnale-stroitelnyj-ekspert (accessed 25 October 2018).

13. Portsevskii A.K. Ventiliatsiia shakht. Aerologiia karerov [Mine ventilation. Quarries aerology]. Moscow, MGOU, 2004, 71 p.

14. Overview of mining and its impacts, available at: https://www.elaw.org/files/mining-eia-guidebook/ Chapter1.pdf (accessed 25 October 2018).

15. Trubetskoi K.N., Galchenko Iu.P., Kalabin G.V., Proshliakov A.N. Geotekhnologicheskaia paradigma 
razvitiia kompleksnogo osvoeniia nedr $\mathrm{v}$ Arkticheskoi zone Rossii [Geotechnological paradigm of development of integrated mineral resources development in the Arctic zone of Russia]. Arktika: ekologiia i ekonomika, 2015, no.3 (19), pp.54-65.

16. Voronov E.T. Borba s pyliu pri razvedke mestorozhdenii $\mathrm{v}$ usloviiakh vechnoi merzloty [Fighting dust in exploration in permafrost]. Moscow, Nedra, 1977, 93 p.

17. Mikhailov V.A., Beresnevich P.V., Borisov V.G., Loboda A.I. Borba $\mathrm{s}$ pyliu $\mathrm{v}$ rudnykh karerakh [Fighting dust in ore quarries]. Moscow, Nedra, 1981, $262 \mathrm{p}$.

18. Mikhailov V.A., Beresnevich P.V. Nauchnotekhnicheskii prognoz razvitiia sposobov i sredstv borby $\mathrm{s}$ pyliu i vrednymi gazami pri otkrytoi razrabotke [Scientific and technical forecast of the development of methods and means of combating dust and harmful gases in open development]. Mining Journal, 1975, no.4, pp.69-72.

19. Bulbashev A.P., Shuvalov Iu.V. Borba s pyliu na karerakh po dobyche stroitelnykh materialov [Fighting dust in quarries for the extraction of building materials]. Saint Petersburg, MANEB, 2006, 208 p.

20. Dalbaeva E.P. Razrabotka sposoba umensheniia riska profes-sionalnykh zabolevanii na karerakh kriolitozony [Development of a method for reducing the risk of occupational diseases in cryolithozone quarries]. Mezhdunarodnaia nauchnoprakticheskaia konferentsiia, posviashchennaia 10-letnemu iubileiu gornogo otdeleniia ulanudenskogo inzhenerno-pedagogicheskogo kolledzha. Ulan-ude, 2013, pp.37-41.

21. Profilaktika professionalnykh zabolevanii [Prevention of occupational diseases], available at: https://www.ilo.org/wcmsp5/groups/public/---europe/ --ro-geneva/---sro-moscow/docu-ments/genericdocument/wcms_312005.pdf (accessed 25 October 2018).

22. Zhukova T.V. Gigienicheskie voprosy diagnostiki individualnogo zdorovia [Hygienic issues of diagnosing individual health]. Rostov, Rostovskii gosudarstvennyi meditsinskii universitet, $2000,58 \mathrm{p}$.

23. Kislitsyna V.V., Motuz I.Iu. Pylevoi faktor na predpriiatiiakh ugolnoi promyshlennosti [Dusty factor on the enterprises of the coal industry].
Sovremennye nauchnye issledovaniia i innovatsii, 2014, no.4, part 2, available at: http://web.snauka.ru/ issues/2014/04/32001 (accessed 25 October 2018).

24. Kislitsyna V.V., Korsakova T.G., Motuz I.Iu. Osobennosti uslovii truda i professionalnogo riska rabotnikov, zaniatykh pri otkrytoi dobyche uglia [Features of working conditions and occupational risk of workers engaged in opencast coal mining]. Mezhdunarodnyi zhurnal prikladnykh fundamentalnykh issledovanii, 2013, no.4, pp.52-55.

25. Timofeeva S.S., Murzin M.A. Pylevaia nagruzka pri dobyche uglia i professionalnye riski [Dust load in coal mining and occupational hazards]. Vestnik Irkutskogo gosudarstvennogo tekhnicheskogo universiteta, 2015, no.5, pp.68-71.

26. Global trends and challenges on occupational safety and health: ILO introductory report, available at: https:/www.ilo.org/wcmsp5/groups/public/@ed_protect/ @protrav/@safework/documents/publication/wcms_ 162662.pdf (accessed 25 October 2018).

27. Occupational disease in mines, available at: https://www.labour.gov.on.ca/english/hs/sawo/ pubs/fs_miningdisease.php (accessed 25 October 2018).

28. Velichkovskii B.T. O fiziko-khimicheskikh svoistvakh kremnezema, obuslovlivaiushchikh razvitie silikoza [On the physico-chemical properties of silica, causing the development of silicosis]. Patogenez pnevmokoniozov. Sverdlovsk, 1970, pp.213-218.

29. O sostoianii professionalnoi zabolevaemosti $v$ Rossiiskoi Federatsii v 2013 g. [On the state of occupational morbidity in the Russian Federation in 2013]. Informatsionnyi sbornik statei $i$ analiticheskikh materialov. Moscow, Federalnoe gosudarstvennoe zdravookhranenie, 2013, 109 p.

30. O sostoianii sanitarno-epidemiologicheskogo blagopoluchiia naseleniia v Rossiiskoi Federatsii v 2014 godu [On the state of sanitary and epidemiological well-being of the population in the Russian Federation in 2014]. Gosudarstvennyi doklad. Moscow, Federalnaia sluzhba po nadzoru v sfere zashchity prav potrebitelei i blagopoluchiia cheloveka, 2015, $206 \mathrm{p}$.

31. Galkin K.A., Ishchuk I.G., Zaburdiaev G.S. Vliianie geologicheskikh osobennostei ugolnykh plastov na zabolevaemost rabochikh pnevmokoni- 
ozami: ekspress-informatsiia [Influence of geological features of coal seams on the incidence of workers with pneumoconiosis: express information]. Moscow, TsNIEiugol, 1980, 8 p.

32. Trubitsyn A.A., Poliakova G.G., Morozova N.V. $\mathrm{O}$ sostoianii professionalnoi zabolevaemosti na predpriiatiiakh ugolnoi promyshlennosti [On the state of occupational morbidity in coal industry enterprises]. Preduprezhdenie travmatizma $i$ avarii $v$ ugolnykh shakhtakh $i$ na razrezakh. Sbornik nauchnykh trudov. Kemerovo, 1999, pp.89-91.

33. Zaidenvarg V.E. Strukturnye preobrazovaniia v ugolnoi promyshlennosti Rossii [Structural transformations in the coal industry of Russia]. Energeticheskaia politika, 1999, no.3, pp.25-31.

34. Salamatin A.G. Ugolnaia promyshlennost Rossii: problemy i vozmozhnosti ustoichivogo razvitiia [Coal industry of Russia: problems and opportunities for sustainable development]. Energeticheskaia politika, 1999, no.3, pp.16-20.

35. Borba s silikozom [Fight against silicosis]. Sbornik statei. Moscow, Izdatelstvo Akademii nauk SSSR, 1955, vol.2, $30 \mathrm{p}$.

36. Rukovodstvo po gigienicheskoi otsenke faktorov rabochei sredy $i$ trudovogo protsessa. Kriterii i klassifikatsiia uslovii truda [Guidance on the hygienic assessment of factors of the working environment and the labor process. Criteria and classification of working conditions]. Rukovodstvo R 2.2.2006-05, utverzhdeno glavnym gosudarstvennym sanitarnym vrachom RF 29 iiulia 2005 g. Moscow, 2005, 156 p.

37. Airborne irritant induced bronchitis, available at: https://www.dovemed.com/diseases-conditions/ airborne-irritant-induced-bronchitis (accessed 25 October 2018).

38. Romanchenko S.B., Rudenko Iu.F., Kosterenko V.N. Pylevaia dinamika v ugolnykh shakhtakh [Dust dynamics in coal mines]. Gornoe delo, 2011, vol.6, book 9, 255 p.

39. Profilaktika professionalnykh zabolevanii: doklad MOT k Vsemirnomu dniu okhrany truda [Prevention of occupational diseases: ILO report on World Labor Day]. Sbornik materialov respublikanskoi nauchno-prakticheskoi konferentsii. Cheboksary, 2013.

40. Doklad o sostoianii okruzhaiushchei prirodnoi sredy g. Volgograda v 1998 g. [Report on the state of the environment in Volgograd in 1998]. Ed. S.v. Kosenkova. Volgograd, Volzhskii poligraficheskii kombinat, 1999, $319 \mathrm{p}$.

41. Kasparov A.A. Gigiena truda i promyshlennaia sanitariia [Occupational health and industrial sanitation]. Moscow, 1981, $384 \mathrm{p}$.

42. Laney A.S., Weissman D.N. Respiratory diseases caused by coal mine dust. Journal of occupational and environmental medicine, available at: https://www.ncbi.nlm.nih.gov/pmc/ articles/PMC 4556416/ (accessed 25 October 2018).

43. Reclamation of degraded landscapes due to opencast mining, advances in landscape architecture, available at: https://www.intechopen.com/books/advances-in-landscape-architecture/ reclamation-of-degraded-landscapes-due-to-opencastmining (accessed 25 October 2018).

44. Gasparian N.A. Pylepodavlenie na osnove ispolzovaniia fazovykh perekhodov vlagi pri vedenii otkrytykh gornykh rabot [Dust suppression based on the use of moisture phase transitions in open pit mining]. Ph. D. thesis. Saint Petersburg, $2008,185 \mathrm{p}$.

45. Dikarev V.I., Rogalev V.A., Denisov V.A. et al. Metody i sredstva zashchity cheloveka i okruzhaiushchei sredy [Methods and means of protecting people and the environment]. Saint Petersburg, MANEB, 1999, $186 \mathrm{p}$.

46. Ivanov A.V. Snizhenie aerozolnogo zagriazneniia atmosfernogo vozdukha ot proizvodstvennykh obektov OAO "Kovdorskii GOK" [Reduction of aerosol pollution of atmospheric air from production facilities of OJSC "Kovdorsky GOK"]. Ph. D. thesis. Saint Petersburg, 2015, 206 p.

47. Bulbashev A.P., Gasparian N.A., Kovshov S.V., Nikulin A.N., Smirnov Iu.D., Shuvalov Iu.V. Ratsionalnaia organizatsiia dobychi poleznykh iskopaemykh $\mathrm{v}$ karerakh so slozhnymi usloviiami truda gornorabochikh [Rational organization of mining in quarries with difficult working conditions for miners]. Saint Petersburg, MANEB, 2009, $464 \mathrm{p}$.

48. Bulbashev A.P., Shuvalov Iu.V. ratsionalnye tekhnologii osvoeniia mestorozhdenii stroitelnykh materialov [Rational technologies for the development of building materials deposits]. Saint Petersburg, MANEB, 2000, 234 p. 
49. Ishchuk I.G., Podobrazhin S.N. Metodologicheskie osnovy vybora effektivnykh sostavov zhidkostei dlia predvaritelnogo uvlazhneniia ugolnogo massiva [Methodological basis for the selection of effective compositions of liquids for the preliminary moistening of a coal massif]. Borba s silikozom. Moscow, Nauka, 1986, vol.12, pp.26-33.

50. Kachurin N.M., Riabov R.G. kompleksnoe ispolzovanie otkho-dov - effektivnyi sposob okhrany okruzhaiushchei sredy [Integrated waste management - an effective way to protect the environment]. Resursosberegaiushchie tekhnologii, Moscow, 1997, no.6, pp.18.

51. Korobova N.L. Ekologiia i gornoe proizvodstvo [Ecology and mining industry]. Magnitogorsk, MGTU, 2001, 456 p.

52. Ivanov A.V., Smirnov Iu.D., Kamenskii A.A. Ispolzovanie parokondensatsionnogo sposoba pylepodavleniia pri razlichnykh tekhnologicheskikh operatsiiakh dobychi poleznykh iskopaemykh [The use of steam-condensation method of dust suppression at various technological operations of mining]. Zapiski Gornogo instituta. Saint Petersburg, Gornyi universitet, 2009, vol.186, pp. 82-85.

53. Kudriashov V.V., Voronina Iu.V. Napravlenie $\mathrm{V}$ razrabotke priborov pylevogo kontrolia [Direction in the development of dust control devices]. Problemy sovremennoi rudnichnoi aerologii. Moscow, Nauka, 1974, pp.208-214.

54. Kudriashov V.V. Nauchnye osnovy gidroobespylivaniia shakht Severa [The scientific basis of hydrospray the mines of the North]. Moscow, Nauka, 1984, 264 p.

55. Kudriashov V.V. Nekotorye voprosy teorii i raschet optiche-skikh pyleizmeritelnykh priborov [Some questions of the theory and calculation of optical dust measuring devices]. Borba s silikozom. Sverdlovsk, UFAN SSSR, 1960, vol.III, pp.161-162.

56. Ivashkin B.C. Borba s pyliu i gazami na ugolnykh razrezakh [Fighting dust and gas in coal mines]. Moscow, Nedra, 1980, 153 p.

57. Kovshov S.V. Obosnovanie parametrov biogennogo sposoba snizheniia aerotekhnogennogo vozdeistviia vneshnikh otvalov na rabochee prostranstvo karerov stroitelnykh materialov
[Substantiation of the parameters of the biogenic method of reducing the aerotechnogenic impact of external dumps on the working space of quarries of building materials]. Ph. D. thesis. Saint Petersburg, 2010, $172 \mathrm{p}$.

58. Zinovev A.P., Kupin A.N., Olkov P.L., Maksimov G.G. Borba s pyleobrazovaniem na karernykh avtodorogakh neftianymi viazhushchimi [Fighting dust on oil roads on open roads]. Ufa, Bashkirskoe knizhnoe izdatelstvo, 1990, $95 \mathrm{p}$.

59. Opytno-promyshlennye ispytaniia profilakticheskogo sredstva RNKh-1020 TU 0258006-73761066-2011 proizvodstva ZAO IPK "Rosneftekhim", pylepodavlenie na tekhnologicheskikh avtomobilnykh dorogakh filiala "Ugolnyi razrez "Korkinskii" [Pilot tests of the prophylactic agent RNH-1020 TU 0258-006-73761066-2011 produced by CJSC IPK Rosneftekhim, dust suppression on the technological highways of the Korkinsky coal mine branch]. Otchet o vypolnennykh rabotakh. Korkino, 2012.

60. Brigadin I.V., Bogarchuk V.S., Dobritsa Iu.V., Esenina N.A., Nesterov A.G., Krapivin S.V. Sposob pylepodavleniia pri vzryvnykh rabotakh [Method of dust suppression during blasting]. Patent Russian Federation 2273738, 2006.

61. Air pollution control, available at: https://www.britannica.com/technology/air-pollutioncontrol (accessed 25 October 2018).

62. Hazard prevention and control in the work environment: Airborne dust (WHO, 1999), available at: http://www.who.int/occupational_ health/publica-tions/airdust/en/ (accessed 25 October 2018).

63. Personal protective equipment guidelines, available at: http://www.safety.uwa.edu.au/ topics/physical/protective-equipment (accessed 25 October 2018).

64. Basmanov P.I., Kaminskii S.L., Korobeinikova A.V., Trubitsyna M.E. Sredstva individualnoi zashchity organov dykhaniia: spravochnoe rukovodstvo [Personal respiratory protective equipment: reference guide]. Saint Petersburg, Iskusstvo Rossii, 2002, $400 \mathrm{p}$.

65. Rukovodstvo po borbe $\mathrm{s}$ pyliu i pylevzryvozashchite na ugolnykh i slantsevykh razrezakh, utverzhdennoe Ministerstvom ugolnoi 
promyshlennosti SSSR 26 aprelia $1990 \mathrm{~g}$. [Guidelines for combating dust and dust and explosion protection in coal and shale cuts, approved by the Ministry of Coal Industry of the USSR on April 26, 1990], available at: http://docs.cntd.ru/docu-ment/1200093007 (accessed 25 October 2018).

66. Piramidina N.G. Kondensatsionnyi metod podavleniia pyli pri peregruzke gornoi massy $\mathrm{v}$ karerakh $\mathrm{v}$ usloviiakh otritsatelnykh temperatur [Condensation method of suppressing dust during overloading of the rock mass in quarries at negative temperatures]. Abstract of $\mathrm{Ph}$. D. thesis. Alma-Ata, 1984, $17 \mathrm{p}$.

67. Piramidina N.G. Kondensatsionnyi metod pylepodavleniia na otkrytykh gornykh rabotakh [Condensation method of dust control in open pit mining]. Trudy tsentralnogo nii proektnokonstruktorskogo instituta profilaktiki pnevmokoniozov $i$ tekhniki bezopasnosti, 1976, iss.15, pp.40-43.
68. Piramidina N.G. Rezultaty laboratornykh issledovanii kondensatsionnogo podavleniia pyli pri otritsatelnykh temperaturakh vozdukha [The results of laboratory studies of condensation suppression of dust at negative air temperatures]. Trudy instituta Unipromed. Sverdlovsk, 1977, iss.XX, pp.83-86.

69. Zaburdiaev G.S. Zashchita organov dykhaniia shakhterov [Miners respiratory protection]. Okhrana truda i sotsialnoe strakhovanie, 2001, no.2, pp. 68-69.

70. Respiratory protection: the right respirator, available at: http://www.covwc.com/templates/System/ details.asp? $\mathrm{id}=48008 \& \mathrm{PG}=$ resources $\& \mathrm{CID}=30429$ (accessed 25 October 2018).

71. Bulbashev A.P., Gasparian N.A., Kovshov S.V., Nikulin A.N., Smirnov Iu.D., Shuvalov Iu.V. Ratsionalnaia organizatsiia dobychi poleznykh iskopaemykh v karerakh so slozhnymi usloviiami truda gornorabochikh [Rational organization of mining in quarries with difficult working conditions for miners]. Saint Petersburg, MANEB, 009, $464 \mathrm{p}$.

\section{Библиографический список}

1. World of molecules [Электронный pecypc]. URL: https://www.worldofmole-cules.com/fuels/ coal7b.htm (дата обращения: 25.10.2018).

2. The Guardian [Электронный ресурс]. - URL: https://www.theguardian.com/commentis-free/2009/ feb/15/james-hansen-power-plants-coal

(дата обращения: 25.10.2018).

3. Coal's decade of stagnation [Электронный pecypc] / International Energy Agency. - URL: https://www.iea.org/coal2017 (дата обращения: 25.10.2018).

4. The prevention and control of fire and explosion in mines [Электронный pecypc] / Deep Mined Coal Industry Advisory Committee, The Mining Association of the United Kingdom. - URL: http://www. hse.gov.uk/mining/feguidance.pdf (дата обращения: 25.10.2018).

5. Независимое аналитическое агентство «Росинформуголь» [Электронный ресурс] / под ред. Г.Л. Краснянского; Российский уголь. URL: https://www.rosugol.ru/index.php. (дата обращения: 25.10.2018).

6. Does the U.S. stand a chance against Russia's icebreakers? [Электронный pecypc] - URL: https://www.popularmechanics.com/mili-tary/navy- ships/a19673250/future-icebreakers (дата обращения: 25.10.2018).

7. Трубецкой К.Н. Геотехнологическая парадигма развития комплексного освоения недр в Арктической зоне России / ФГБУН «Институт проблем комплексного освоения недр РАН». Москва, 2015. - 12 с.

8. Kolmar South Yakutia coal [Электронный pecypc]. - URL: http://www.kolmar.ru/upload/ iblock/b0d/b0dceaf5729be2ae739e9599a0f06911.pdf (дата обращения: 25.10.2018).

9. Российская газета [Электронный ресурс]. URL: http://www.rg.ru/2009/03/30/arktika-osnovydok.html (дата обращения: 25.10.2018).

10. The development strategy of the Arctic zone of the Russian Federation. [Электронный ресурс]. URL: http://www.iecca.ru/en/legis-lation/strategies/ item/99-the-development-strategy-of-the-arctic-zoneof-the-russian-federation (дата обращения: 25.10.2018).

11. Освоение угольных месторождений в удаленных районах северо-востока Арктики основа обеспечения энергобезопасности населения региона [Электронный ресурс] / Ткач С.М. [и др.]; ИГДС СО РАН. URL: https://docplayer.ru/32006093-Osvoenie-ugolnyh- 
mesto-rozhdeniy-v-udalennyh-raonah-severo-vostoka-arktiki-osnova-obespecheniya-energobezopasnostinaseleniya-regiona.html (дата обращения: 25.10.2018).

12. Институт промышленного гражданского проектирования [Электронный ресурс]. URL: http://2k-project.ru/ob-institute/sobytiya_i novosti/news/news_2k/ctatya-v-zhurnale-stroitelnyjekspert (дата обращения: 25.10.2018).

13. Порцевский А.К. Вентиляция шахт. Аэрология карьеров. - Москва: МГОУ, 2004. - 71 с.

14. Overview of mining and its impacts [Электронный ресурc]. - URL: https://www.elaw.org/ files/mining-eia-guidebook/Chapter1.pdf (дата обращения: 25.10.2018).

15. Геотехнологическая парадигма развития комплексного освоения недр в Арктической зоне России / К.Н. Трубецкой, Ю.П. Галченко, Г.В. Калабин, А.Н. Прошляков // Арктика: экология и экономика. - 2015. - № 3 (19). С. $54-65$.

16. Воронов Е.Т. Борьба с пылью при разведке месторождений в условиях вечной мерзлоты. - Москва: Недра, 1977. - 93 с.

17. Борьба с пылью в рудных карьерах / В.А. Михайлов, П.В. Бересневич, В.Г. Борисов, А.И. Лобода. - Москва: Недра, 1981. - 262 с.

18. Михайлов В.А., Бересневич П.В. Научнотехнический прогноз развития способов и средств борьбы с пылью и вредными газами при открытой разработке // Горный журнал. - 1975. № 4. - С. 69-72.

19. Бульбашев А.П., Шувалов Ю.В. Борьба с пылью на карьерах по добыче строительных материалов. - Санкт-Петербург: МАНЭБ, 2006. $-208 \mathrm{c}$.

20. Далбаева Е.П. Разработка способа уменьшения риска профессиональных заболеваний на карьерах криолитозоны // Международная научно-практическая конференция, посвященная 10-летнему юбилею горного отделения Улан-Удэнского инженернопедагогического колледжа. - Улан-Удэ, 2013. C. $37-41$.

21. Профилактика профессиональных заболеваний: доклад [Электронный ресурс] / MOT, 2013. URL: https://www.ilo.org/wcmsp5/groups/public/--europe/---ro-geneva/---sro-mos-cow/documents/genericdocument/wcms_312005.pdf (дата обращения: 25.10.2018)
22. Жукова Т.В. Гигиенические вопросы диагностики индивидуального здоровья / Ростовский государственный медицинский университет. - Ростов, 2000. - С. 58.

23. Кислицына В.В., Мотуз И.Ю. Пылевой фактор на предприятиях угольной промышленности [Электронный ресурс] // Современные научные исследования и инновации. - 2014. № 4. - Ч. 2. - URL: http://web.snauka.ru/ issues/2014/04/32001 (дата обращения: 25.10.2018).

24. Кислицына В.В., Корсакова Т.Г., Мотуз И.Ю. Особенности условий труда и профессионального риска работников, занятых при открытой добыче угля // Международный журнал прикладных фундаментальных исследований 2013. - № 4. - С. 52-55.

25. Тимофеева С.С., Мурзин М.А. Пылевая нагрузка при добыче угля и профессиональные риски // Вестник Иркутского государственного технического университета. - 2015. - № 5. C. $68-71$.

26. Global trends and challenges on occupational safety and health: ILO introductory report [Электронный ресурс] // XIX World Congress on Safety and Health at Work. - Istanbul, 2011. URL: https://www.ilo.org/wcmsp5/groups/public/ @ed_protect/@protrav/@s afework/documents/publication/wcms_162662.pdf (дата обращения: 25.10.2018).

27. Occupational disease in mines [Электронный pecypc]. - URL: https://www.la-bour.gov.on.ca/ english/hs/sawo/pubs/fs_miningdi-sease.php (дата обращения: 25.10.2018).

28. Величковский Б.Т. О физико-химических свойствах кремнезема, обусловливающих развитие силикоза // Патогенез пневмокониозов. Свердловск, 1970. - С. 213-218.

29. О состоянии профессиональной заболеваемости в Российской Федерации в 2013 г.: информационный сборник статей и аналитических материалов. - Москва: Федеральное государственное здравоохранение, 2013. $109 \mathrm{c}$.

30. O состоянии санитарно-эпидемиологического благополучия населения в Российской Федерации в 2014 году: государственный доклад. Москва: Федеральная служба по надзору в сфере защиты прав потребителей и благополучия человека, 2015. - 206 с. 
31. Галкин К.А., Ищук И.Г., Забурдяев Г.С. Влияние геологических особенностей угольных пластов на заболеваемость рабочих пневмокониозами: экспресс-информация. Москва: ЦНИЭИуголь, 1980. - 8 с.

32. Трубицын А.А., Полякова Г.Г., Морозова Н.В. О состоянии профессиональной заболеваемости на предприятиях угольной промышленности // Предупреждение травматизма и аварий в угольных шахтах и на разрезах: сборник научных трудов / ВостНИИ. - Кемерово, 1999. C. 89-91.

33. Зайденварг В.Е. Структурные преобразования в угольной промышленности России // Энергетическая политика. - 1999. - № 3. C. 25-31.

34. Саламатин А.Г. Угольная промышленность России: проблемы и возможности устойчивого развития // Энергетическая политика. - 1999. № 3. - C. 16-20.

35. Борьба с силикозом: сборник статей. Москва: Издательство Академии наук СССР, 1955. - T. 2. $-30 \mathrm{c}$.

36. Руководство по гигиенической оценке факторов рабочей среды и трудового процесса. Критерии и классификация условий труда: Руководство Р 2.2.2006-05: утв. Главным государственным санитарным врачом РФ 29 июля 2005 г. - Москва, 2005. - 156 с.

37. Airborne irritant induced bronchitis [Электронный ресурc]. - URL: https://www.dovemed.com/diseases-conditions/air-borne-irritant-induced-bronchitis (дата обращения: 25.10.2018).

38. Романченко С.Б., Руденко Ю.Ф., Костеренко В.Н. Пылевая динамика в угольных шахтах // Горное дело. - 2011. - Т. 6, кн. 9. $255 \mathrm{c}$.

39. Профилактика профессиональных заболеваний: доклад МОТ к Всемирному дню охраны труда // Сборник материалов республиканской научно-практической конференции. - Чебоксары, 2013.

40. Доклад о состоянии окружающей природной среды г. Волгограда в 1998 г. / под общ. ред. С.В. Косенковой. - Волгоград: Волжский полиграфический комбинат, 1999. $319 \mathrm{c}$.

41. Каспаров А.А. Гигиена труда и промышленная санитария. - Москва, 1981. $384 \mathrm{c}$.
42. Laney A.S., Weissman D.N. Respiratory diseases caused by coal mine dust [Электронный pecypc] // Journal of occupational and environmental medicine. DOI: 10.1097/JOM.0000000000000260. URL: $\quad$ https://www.ncbi.nlm.nih.gov/pmc/articles/PMC4556416/ (дата обращения: 25.10.2018).

43. Reclamation of degraded landscapes due to opencast mining, advances in landscape architecture [Электронный ресурс] DOI: 10.5772/55796. - URL: https://www.intechopen.com/books/advances-in-landscape-architecture/reclamation-of-degraded-landscapesdue-to-opencast-mining (дата обращения: 25.10.2018).

44. Гаспарьян Н.A. Пылеподавление на основе использования фазовых переходов влаги при ведении открытых горных работ: диссертация на соискание ученой степени кандидата технических наук: 05.26.01 / Гаспарьян Никита Александрович. - Санкт-Петербург, 2008. - $185 \mathrm{c}$.

45. Методы и средства защиты человека и окружающей среды / В.И. Дикарев, В.А. Рогалев, В.А. Денисов [и др.]. - Санкт-Петербург: МАНЭБ, 1999. - 186 с.

46. Иванов А.В. Снижение аэрозольного загрязнения атмосферного воздуха от производственных объектов ОАО «Ковдорский ГОК»: диссертация на соискание ученой степени кандидата технических наук: 25.00.36 / Иванов Андрей Владимирович. - Санкт-Петербург, 2015. - 206 c.

47. Рациональная организация добычи полезных ископаемых в карьерах со сложными условиями труда горнорабочих / А.П. Бульбашев, Н.А. Гаспарьян, С.В. Ковшов, А.Н. Никулин, Ю.Д. Смирнов, Ю.В. Шувалов. - Санкт-Петербург: МАНЭБ, 2009. - 464 с.

48. Бульбашев А.П., Шувалов Ю.В. Рациональные технологии освоения месторождений строительных материалов. - СанктПетербург: МАНЭБ, 2000. - 234 с.

49. Ищук И.Г., Подображин С.Н. Методологические основы выбора эффективных составов жидкостей для предварительного увлажнения угольного массива // Борьба с силикозом. - Москва: Наука, 1986. - Т. 12. C. $26-33$.

50. Качурин Н.М., Рябов Р.Г. Комплексное использование отходов - эффективный способ 
охраны окружающей среды // Ресурсосберегающие технологии. - Москва, 1997. № 6. - C. 18 .

51. Коробова Н.Л. Экология и горное производство. - Магнитогорск: МГТУ, 2001. $456 \mathrm{c}$.

52. Иванов А.В., Смирнов Ю.Д., Каменский А.А. Использование пароконденсационного способа пылеподавления при различных технологических операциях добычи полезных ископаемых // Записки Горного института. - Санкт-Петербург: Горный университет, 2009. - Т. 186. C. $82-85$.

53. Кудряшов В.В., Воронина Ю.В. Направление в разработке приборов пылевого контроля // Проблемы современной рудничной аэрологии. - Москва: Наука, 1974. C. 208-214.

54. Кудряшов В.В. Научные основы гидрообеспыливания шахт Севера. - Москва: Наука, 1984. - 264 c.

55. Кудряшов В.В. Некоторые вопросы теории и расчет оптических пылеизмерительных приборов // Борьба с силикозом. Свердловск: УФАН СССР, 1960. - Т. III. С. $161-162$.

56. Ивашкин В.С. Борьба с пылью и газами на угольных разрезах. - Москва: Недра, 1980. $153 \mathrm{c}$.

57. Ковшов С.В. Обоснование параметров биогенного способа снижения аэротехногенного воздействия внешних отвалов на рабочее пространство карьеров строительных материалов: диссертация на соискание ученой степени кандидата технических наук: 05.26.01 / Ковшов Станислав Вячеславович. - Санкт-Петербург, 2010. - $172 \mathrm{c}$.

58. Борьба с пылеобразованием на карьерных автодорогах нефтяными вяжущими / А.П. Зиновьев, А.Н. Купин, П.Л. Ольков, Г.Г. Максимов. Уфа: Башкирское книжное издательство, 1990. -95 c.

59. Опытно-промышленные испытания профилактического средства РНХ-1020 ТУ 0258-006-73761066-2011 производства ЗАО ИПК «Рос-нефтехим», пылеподавление на технологических автомобильных дорогах филиала «Угольный разрез “Коркинский”»: отчет о выполненных работах. - Коркино, 2012.
60. Способ пылеподавления при взрывных работах: патент Российская Федерация 2273738 / Бригадин И.В., Богарчук В.С., Добрица Ю.В., Есенина Н.А., Нестеров А.Г., Крапивин С.В.; 2006. - Бюл. № 10.

61. Air pollution control [Электронный pecypc]. URL: https://www.britannica.com/technology/ air-pollution-control (дата обращения: 25.10.2018).

62. Hazard prevention and control in the work environment: Airborne dust (WHO, 1999) [Электронный ресурс]. - URL: http://www.who.int/ occupational_health/publications/airdust/en/ (дата обращения: 25.10.2018).

63. Personal protective equipment guidelines [Электронный ресурс]. - URL: http:/www.safety. uwa.edu.au/topics/physical/protective-equipment (дата обращения: 25.10.2018).

64. Средства индивидуальной защиты органов дыхания: справочное руководство / П.И. Басманов, С.Л. Каминский, А.В. Коробейникова, М.Е. Трубицына. - Санкт-Петербург: Искусство России, 2002. - 400 с.

65. Руководство по борьбе с пылью и пылевзрывозащите на угольных и сланцевых разрезах: утв. Министерством угольной промышленности СССР 26 апреля 1990 г. [Электронный ресурс]. - URL: http://docs.cntd.ru/ document/1200093007 (дата обращения: 25.10.2018).

66. Пирамидина Н.Г. Конденсационный метод подавления пыли при перегрузке горной массы в карьерах в условиях отрицательных температур: автореферат диссертации на соискание ученой степени кандидата технических наук: 05.26.01 / Пирамидина Ната Геннадьевна. - Алма-Ата, 1984. - 17 c.

67. Пирамидина Н.Г. Конденсационный метод пылеподавления на открытых горных работах // Труды Центрального НИИ проектноконструкторского института профилактики пневмокониозов и техники безопасности. 1976. - Вып. 15. - С. 40-43.

68. Пирамидина Н.Г. Результаты лабораторных исследований конденсационного подавления пыли при отрицательных температурах воздуха // Труды института Унипромедь. - Свердловск, 1977. - Вып. ХХ. C. 83-86. 
69. Забурдяев Г.С. Защита органов дыхания шахтеров // Охрана труда и социальное страхование. - 2001. - № 2. - С. 68-69.

70. Respiratory Protection: The Right Respirator [Электронный ресурc]. - URL: http://www.covwc.com/ templates/System/details.asp?id $=48008 \& \mathrm{PG}=$ resources $\& \mathrm{CID}=30429$ (дата обращения: 25.10.2018).
71. Рациональная организация добычи полезных ископаемых в карьерах со сложными условиями труда горнорабочих / А.П. Бульбашев, Н.А. Гаспарьян, С.В. Ковшов, А.Н. Никулин, Ю.Д. Смирнов, Ю.В. Шувалов. - Санкт-Петербург: МАНЭБ, 2009. - 464 c.

Please cite this article in English as:

Sharov N.A., Dudayev R.R., Krishchuk D.I., Liskova M.Yu. Methods of dust suppression at open-pits coal mines of Extreme North. Perm Journal of Petroleum and Mining Engineering, 2019, vol.19, no.2, pp.184-200. DOI: 10.15593/2224-9923/2019.2.8

Просьба ссылаться на эту статью в русскоязычных источниках следующим образом:

Методы пылеподавания на угольных разрезах Крайнего Севера / Н.А. Шаров, Р.Р. Дудаев, Д.И. Крищук, М.Ю. Лискова // Вестник Пермского национального исследовательского политехнического университета. Геология. Нефтегазовое и горное дело. - 2019. - Т.19, №2. - С.184-200. DOI: 10.15593/2224-9923/2019.2.8 